\title{
Editorial
}

\section{In memory of Gianfranco Del Prete: a scientist without borders}

\author{
Salvatore Rubino \\ Editor-in-Chief, The Journal of Infection in Developing Countries
}

J Infect Dev Ctries 2011; 5(9):611-613.

(Received and Accepted 12 September 2011)

Copyright @ 92011 Rubino. This is an open-access article distributed under the Creative Commons Attribution License, which permits unrestricted use, distribution, and reproduction in any medium, provided the original work is properly cited.

This issue of the Journal of Infection in Developing Countries honours the memory of a brilliant scientist, immunologist, teacher and friend, Professor Gianfranco Del Prete, University of Florence, Italy, who passed away 8 November 2010. With respect to his passion for immunology, this issue presents three review articles on the role of immune responses in Yersinia pestis infection, on developing live vaccines against plague, and on Tcell response to bacterial agents $[1,2,3]$. One more article on infectious diseases and autoimmunity will follow in an upcoming issue.

It is very difficult to write a memorial for a dear friend and colleague who passionately devoted his life to science and participated in global cooperation projects to improve the health care in developing countries. His work focused mainly on diseases that affect the health of millions of people worldwide, particularly tuberculosis (TB), parasitic diseases, and the most neglected infectious or forgotten agents such as pestis.

Gianfranco was born in Brescia, Italy, in 1948. After graduating with distinction at the top of his class from the University of Padua (1972) as a medical doctor, he served as a research fellow in basic and clinical immunology. In 1978 he moved to the medical school in the prestigious Institute of Internal Medicine and Immunoallergy at the University of Florence, under the direction of Prof. Mario Ricci, the father of allergology in Italy. Gianfranco was promoted to associate professor and then full professor of Internal Medicine in 1995, working at the Department of Internal Medicine, coordinating a fruitful research group of young scientists. In 2004, he became the director of the Allergy and Clinical Immunology Postgraduate School, where he taught both medical and



postgraduate students. He was also responsible for the patient care unit at the University Hospital of Careggi (SOD Patologia Medica).

Gianfranco was well-known internationally and he spent time as a visiting scientist at several prestigious institutions abroad during his career. Of particular note are his appointments first at the Department of Immunology at Harvard Medical School, Boston, USA, where he worked with Prof. R. Geha, and then at the Basel Institute for Immunology in Basel, Switzerland, where he worked with Dr. A. 
Lanzavecchia. From 2005 until 2008 he made several short visits to The Biodesign Institute, Arizona State University, Phoenix-Tempe, USA, collaborating with Prof. R. Curtis and Prof. C. Arntzen.

His scientific interests and activities were in different areas of basic and clinical immunology, particularly in the pathophysiology of the immune response, the host immune response to pathogens, the pathogenetic aspects of organ-specific autoimmune diseases, and the pathogenesis of allergy. Through his lifetime he contributed more than 200 internationally recognized publications and received distinguished national and international awards.

Gianfranco and his co-workers made significant contributions to the definition of the phenotypic and functional features of T lymphocyte subsets known as Th1 and Th2. In an elegant paper published in the Journal of Experimental Medicine in1991 [4], he demonstrated that Th1 differ from Th2 human $\mathrm{T}$ cell clones not only by their profiles of cytokine secretion, but also for cytolytic potential and mode of help for B cell Ig synthesis. He made many other notable contributions to the understanding of host immune responses to bacterial and parasite pathogens. In the last years his major research activities focused on important scientific issues related to developing countries and his work provided strong evidence for the potential use of plant-derived antigens in an oral vaccine for the prevention of plague [5].

His collaboration with scientists from developing countries began in 2000. Especially important and fruitful from a human point of view was the collaboration with Dr. Oumou Y. Sow, Chief of the Service de Pneumo-Phtisiologie, University Ignace Deen, Conakry, Guinea, in the field of TB. Two important studies were performed at the Service de Pneumo-Phtisiologie in Conakry Hospital dealing with HIV-negative patients affected by TB. The first study, published in 2005, reported that the measurement of IFN- $\gamma$-inducible protein 10 and pentraxin 3 plasma levels are tools for monitoring inflammation and disease activity in Mycobacterium tuberculosis infection and can evaluate the efficacy of therapy [6]. The second study (2006) was performed to evaluate serological correlates of active tuberculosis and of response to antituberculosis treatment in a cohort of HIV-negative patients with pulmonary tuberculosis studied at diagnosis and during treatment, demonstrating that particular serological markers may be predictive of treatment outcome [7].
In 2007 Gianfranco had another interesting experience working with Dr. A. Talarmin and Dr. L. Rahalisson at the Institute Pasteur Madagascar, Antananarivo, Madagascar, on Yersinia pestis, building the immunological basis for a possible innovative vaccine [5].

To address the importance of combating coinfections of neglected infectious diseases, he participated with scientists from 14 different African and European countries at a meeting in Addis Ababa, Ethiopia, 9-11 September 2007.

The important message coming from these outstanding collaborations was that the only possibility for winning the fight against infections in low-income countries is by studying, in the most global way possible, the complex interactions between different infections and conditions of malnourishment [8].

To achieve Gianfranco's goals it will be essential to put in place a sustainable network composed of researchers in disease-endemic countries and researchers in the developed world, which will implement an integrated immunological research effort across disciplines and diseases. This network needs to include a strategy for the promotion of highlevel training pathways for African researchers and sustaining their careers in African institutions, which is the exactly one of the principal goals of JIDC. With these views in mind, Gianfranco embraced with great enthusiasm the aim of JIDC from its inception and he was one of the first reviewers for our journal.

We are proud to dedicate this issue to our friend, and we thank all the authors who collaborated with JIDC on this initiative. I think this is the best way to honor the memory of Gianfranco Del Prete, not just with simple words but with interesting reviews that can be helpful for students, medical doctors, laboratorists and scientists from developing countries.

We are close to his wife Franca and all his family, particularly Marco and Giorgio, and we believe Gianfranco's teaching will not be forgotten.

\section{References}

1. Amedei A, Niccolai E, Marino L, D'Elios MM (2011) Role of immune response in Yersinia pestis infection. J Infect Dev Ctries 5(9):628-639.

2. Sun W, Roland KL, Curtiss R III (2011) Developing live vaccines against plague. J Infect Dev Ctries 5(9):614-627.

3. D'Elios MM, Benagiano M, Della Bella C, Amedei A (2011) $\mathrm{T}$-cell response to bacterial agents. J Infect Dev Ctries; 5(9):640-645.

4. Del Prete GF, De Carli M, Ricci M, Romagnani S (1991) Helper activity for immunoglobulin synthesis of $\mathrm{T}$ helper 
type 1 (Th1) and Th2 human T cell clones: the help of Th1 clones is limited by their cytolytic capacity. J Exp Med 174: 809-813.

5. Del Prete G, Santi L, Andrianaivoarimanana V, Amedei A, Domarle O, D' Elios MM, Arntzen CJ, Rahalison L, Mason HS (2009) Plant-derived recombinant F1, V, and F1-V fusion antigens of Yersinia pestis activate human cells of the innate and adaptive immune system. Int $\mathbf{J}$ Immunopathol Pharmacol 22: 133-43.

6. Azzurri A, Sow OY, Amedei A, Bah B, Diallo S, Peri G, Benagiano M, D'Elios MM, Mantovani A, Del Prete G (2005) IFN-gamma-inducible protein 10 and pentraxin 3 plasma levels are tools for monitoring inflammation and disease activity in Mycobacterium tuberculosis infection. Microbes Infect 7: 1-8.

7. Azzurri A, Kanaujia GV, Sow OY, Bah B, Diallo A, Del Prete G, Gennaro ML (2006) Serological markers of pulmonary tuberculosis and of response to anti-tuberculosis treatment in a patient population in Guinea. Int $\mathbf{J}$ Immunopathol Pharmacol 19: 199-208.
8. Boraschi D, Abebe Alemayehu M, Aseffa A, Chiodi F, Chisi J, Del Prete G, Doherty TM, Elhassan I, Engers H, Gyan B, Harandi AM, Kariuki T, Kironde F, Kouriba B, Langhorne J, Laskay T, Medaglini D, Olesen O, Onyebujoh P, Palma C, Sauerwein R, Sibanda E, Steinhoff U, Tagliabue A, Thiel A, Vahedi M, Troye-Blomberg M (2008) Immunity against HIV/AIDS, malaria, and tuberculosis during co-infections with neglected infectious diseases: recommendations for the European Union research priorities. PLoS Negl Trop Dis 2: e255.

\section{Corresponding author}

Salvatore Rubino

Editor-in-chief

JIDC

Conflict of interests: No conflict of interests is declared. 